\title{
A new combination in the genus Talipariti (Malvaceae)
}

\author{
Uma nova combinação no gênero Talipariti (Malvaceae)
}

\author{
Massimo G. Bovini ${ }^{1}$
}

\begin{abstract}
Abstrat
A new combination reestablishes the species Talipariti pernambucense (Arruda) Bovini, known before as a variety. Morphological and genetic studies by several authors have shown the need to establish this taxon at the specific level. Key words: Brazil, Hibiscus, nomenclature, Talipariti pernambucense, Talipariti tiliaceum.

\section{Resumo}

É restabelecida uma espécie em nova combinação: Talipariti pernambucense (Arruda) Bovini, antes reconhecida como variedade. Estudos morfológicos e genéticos de vários autores, mostraram a necessidade de estabelecer o nível específico deste táxon.

Palavras-chave: Brasil, Hibiscus, nomenclatura, Talipariti pernambucense, Talipariti tiliaceum.
\end{abstract}

\section{Introduction}

Hibiscus is a pantropical genus of the Malvaceae family which contains about 200 species (Fryxell 1988). It is widely cultivated for its beautiful flowers and commonly used in landscaping. Fryxell (2001), analyzing the section Azanza, distinguishes the following morphological characteristics in relation to the other species of the genus: arborescent habit, large-ovate to eliptic leaves, large and oblong stipules, calyx lobate with nectaries on the veins, capsule bearing not only five true septa, but also five false septa; and the largest number of chromosomes in the genus (ca. 100). Fryxell (2001) raises this section to genus level, based on McVaugh's (1945) concepts adapted by Gillis (1971), establishing a new name, Talipariti, which was chosen in accordance with Article 62.3 (McNeill et al. 2006). Saint Hilaire (1825) proposed the generic name Paritium for some species of this group. However, it has the same type specimen as Bupariti and Pariti, previously proposed by Duhamel du Monceau (1760) and Adanson (1763), respectively, and in accordance with Article 14.4 (McNeill et al. 2006) both names are rejected. Currently Talipariti is composed of 22 taxa that are found from southeast Asia to Central and South
America, with one species occurring in Korea, Japan, and coastal Australia (Fryxell 2001).

\section{Materials and Methods}

Herbaria collections from CBM, CEPEC, GUA, $\mathrm{RB}$ and SP were analyzed. The specialized literature was consulted and field expeditions were carried out from 2004 to 2006 to observe and comment on live material.

\section{Results and Discussion}

Talipariti tiliaceum var. tiliaceum and T. tiliaceum var. pernambucense, established by Fryxell (2001), were previously described as species of the genus Hibiscus. However, this author suggests that further studies should reassess their taxonomic status, placing them at the species level. They are very similar, and have been the focus of much controversy, considered by various authors as distinct species, infraspecific taxa or synonyms.

Several studies have been carried out seeking evidence to help clarify this taxonomic impasse. The following are the most important ones: Silva (1966) examined the anatomy of stem, leaves and 
pollen grains; Rocha \& Neves (2000) performed a comprehensive study of leaf anatomy; Silva et al. (2004) analyzed pollen; and finally Takayama et al. (2006) studied the phylogeography and genetics of both populations. All of these studies showed significant differences between the two taxa, suggesting they should be considered as distinct species.

Sivarajan \& Pradeep (1996), in flora of the Indian Peninsula, comment that Talipariti tiliaceum (=Hibiscus tiliaceus) is widely found in the region and that it is probably of Indian origin, also emphasizing the presence of a purple spot in the center of the corolla (the outstanding feature). On the other hand, Standley \& Steyermark (1949), in flora of Guatemala, affirm that the petals of Talipariti tiliaceum (= Hibiscus tiliaceus) become red when senescent, a striking feature of Talipariti tiliaceum var. pernambucense (= Hibiscus pernambucensis), in addition to its occurrence in the New World. Takayama in 2007 (pers. comm.) states that specimens from Malaysia have a purple spot in the center of the corolla and that many reach a height of 20 meters or more.
The main distinguishing features of both species are shown in Table 1, based on the articles and comments above, examined material plus phytogeographic data.

Talipariti pernambucense (Arruda) Bovini, comb. nov. Hibiscus pernambucensis Arruda, Diss. Pl. Brazil 44. 1810. Paritium pernambucense (Arruda) G. Don, Gen. Hist. 1: 485. 1831. Hibiscus tiliaceus subsp. pernambucensis (Arruda) Castellanos, Sellowia 19: 50. 1967. Talipariti tiliaceum var. pernambucense (Arruda) Fryxell, Contr. Univ. Mich. Herb. 23:262. 2001. Type: BRAZIL. PARANÁ: Guaratuba, Boa Vista, margin Sai-Guaçu river, Oliveira 229 (neotype US; isoneotype MBM!, designated by Fryxell 2001).

Selected specimens examined: $T$. pernambucense: BRASIL. PERNAMBUCO: Ponta de Pedras, km 13, 27.III.2005, fl., K. Takayama \& M.G. Bovini (CBM, RB 410552). BAHIA: Porto Seguro, 20.IV.1982, fl. e fr., A.M. Carvalho (CEPEC, RB 255809). RIO DE JANEIRO: Rio de Janeiro, Baía de Sepetiba, 25.12.1967, fl., D. Sucre 2041 (GUA, RB); Magé, $5^{\circ}$ Distrito, 1.I.1991, fl, L.C. Giordano 903 (RB). Parati, Parati-Mirim, 9.XI.1991, fl., L.C. Giordano 1207 (RB); Praia Vermelha, 27.XI.1994, fl., M.G. Bovini 657 (RB, SP). SANTA CATARINA: Florianópolis, Distrito

Table 1 - Comparative characteristics of Talipariti pernambucense (Arruda) Bovini and T. tiliaceum L.

\begin{tabular}{lll}
\hline Characteristics & Talipariti pernambucense & Talipariti tiliaceum \\
\hline Habit & Small trees with open canopy & Generally trees with dense canopy \\
Stipules & Scars markedly curved & Scars slightly curved \\
Leaves & Apical pendulous, at almost a $90^{\circ}$ angle & Parallel to the ground \\
& with the ground & \\
& Coriaceous & Chartaceous \\
& Shiny & Matte \\
& Druses uncommon & Druses very common \\
Corolla & Hypostomatic & Amphistomatic \\
Staminal tube & Yellow, becoming red & Yellow with purple spot at petal base, \\
Stigmas & when senescent & retaining color when senescent \\
Fruit & Long (about 4 cm long) & Short (about 3 cm long) \\
Pollen grains & Yellow & Vinaceous \\
& Ovoid capsules & Globular capsules \\
Occurrence & with attenuated apex, & Pantoporate, spines with acute apex, \\
& sexine thicker than the nexine & nexine thicker than the sexine
\end{tabular}


de Daniela, 18.III.2005, fl., T. Kajita et al. (CBM, RB 410568). T. tiliaceum: praia do Leblon (cultivada), VIII.1941, fl., L. Tatto 357 (GUA, RB); Jardim Botânico (arboreto), 22.II.1991, fl. e fr., B. Kurtz 129 (RB).

\section{Acknowledgments}

I thank Dr. João Marcelo A. Braga, from Instituto de Pesquisas Jardim Botânico do Rio de Janeiro, for his comments on the manuscript.

\section{References}

Adanson, M. 1763. Families dês plantes. 2 vols. Paris.

Duhamel du Monceau, H.L. 1760. Dês semis et plantations dês arbres, et de leur culture. Additions, Paris.

Fryxell, P.A. 1988. Malvaceae of Mexico. Systematic Botany Monographs 25: 1-522.

Fryxell, P.A. 2001. Talipariti (Malvaceae), a segregate from Hibiscus. Contributions from the University of Michigan Herbarium 23: 225-270.

Gillis, W.T. 1971. The systematics and ecology of poison-ivy and poison-oaks (Toxocodendron, Anacardiaceae). Rhodora 73: 72-159, 161-237, 370443, 465-540.

McNeill, J.; Barrie, F.R.; Burdet, H.M.; Demoulin, V.; Hawksworth, D.L.; Marhold, K.; Nicolson, D.H.; Prado, J.; Silva, P.C.; Skog, J.E.; Wiersema, J.H. \& Turland, N.J. (eds.). 2006. International Code of
Botanical Nomenclature (Vienna Code). Adopted by the Seventeenth International Botanical Congress Vienna, Austria, July 2005. Regnum Vegetabile 146. A.R.G. Gantner Verlag, Ruggell. 181p.

McVaugh, R. 1945. The genus Triodanis Rafinesque and its relationship to Specularia and Campanula. Wrightia 1: 13-52.

Rocha, J.F. \& Neves, L.J. 2000. Anatomia foliar de Hibiscus tiliaceus L. e Hibiscus pernambucensis Arruda (Malvaceae). Rodriguésia 51: 113-132.

Saint-Hilaire, A. 1825. Flora brasiliae meridionalis. Vol. 1. A. Belin, Paris. 256p.

Silva, S.A.F. 1966. Notas sobre a anatomia e pólen de Hibiscus tiliaceus e H. pernambucensis. Sellowia 18: 105-108.

Silva, F.H.M.; Oliveira, P.P. \& Santos, F.A.R. 2004. Morfologia polínica de Hibiscus pernambucensis Arruda e Hibiscus tiliaceus L. (Malvaceae). Acta Biológica Leopoldensia 26: 203-211.

Sivarajan,V.V. \& Pradeep, A.K. 1996. Malvaceae of Southern Peninsular India: a taxonomic monograph. Daya Publish House, Delhi. 312p.

Standley, P.C. \& Steyermark, J.A. 1949. Malvaceae. In: Flora of Guatemala. Fieldiana, Bot. 24: 324-386.

Takayama, K.; Kajita, T.; Murata, J. \& Tateishi, Y. 2006. Phylogeography and genetic structure of Hibiscus tiliaceus speciation of a pantropical plant with seadrifted seeds. Molecular Ecology 15: 2871-2881. 